\title{
Features of Two Cases with 18q Deletion Syndrome
}

\author{
Elif Özsu, Gül Yeşiltepe Mutlu, Ayşegül Büte Yüksel, Şükrü Hatun \\ Kocaeli University Medical Faculty, Department of Pediatric Endocrinology and Diabetes, Kocaeli, Turkey
}

\begin{abstract}
The $18 \mathrm{q}$ Deletion syndrome is seen in 1 out of 10000 live births. The main features of the syndrome are short stature, hearing loss, hypotonia, mental retardation, endocrine disorders and autoimmunity. Here, we present 2 patients with this syndrome admitted to our clinic who were found to have insulin resistance in addition to mental retardation, short stature, autoimmune thyroiditis and hearing loss. The need to perform a karyogram analysis in cases presenting with these features is emphasized.
\end{abstract}

Key words: $18 q$ deletion, MC4R, autoimmunity

Conflict of interest: None declared

Received: 09.10 .2013

\section{Introduction}

The incidence of 18q Deletion syndrome is reported as 1 in 10000 live births. The characteristic features of the syndrome are short stature, hearing loss, hypotonia, mental retardation and endocrine disorders, accompanied by autoimmunity (1).

We report two patients with this syndrome, admitted to our clinic with various symptoms including insulin resistance (IR) in addition to mental retardation, short stature, autoimmune thyroiditis and hearing loss. The aim of this report is to underline the phenotypic features and endocrine disorders typical for this syndrome and to emphasize the need for karyograms in patients with these findings.

\section{Case Report 1}

A female patient aged 12 years and 3 months was referred to the pediatric endocrinology outpatient clinic from the cardiology department for her short stature. Birth was by normal vaginal delivery and was difficult but did not require the hospitalization of the infant. Birth weight was $2500 \mathrm{~g}$. She was reported to have acquired head control by the $3^{\text {rd }}$ month of life but was noted to be retarded in her neuromotor development at age 6 months and was able to walk at age 2.5 years. Hearing impairment was identified when she was 7 years old. Based on her Denver Development Test results which indicated defective neuromotor development, it was recommended that she receive special education. At age 11 years, she had been diagnosed to have aortic stenosis and was being followed by the cardiology department. Her two siblings and her non-consanguineous parents were healthy. The patient's weight was $41 \mathrm{~kg}[-0.8$ standard deviation score (SDS)], height $133.5 \mathrm{~cm}(-3.5$ SDS) and head circumference was $50 \mathrm{~cm}$.

Address for Correspondence

Elif Özsu MD, Kocaeli University Medical Faculty, Department of Pediatric Endocrinology and Diabetes, Kocaeli, Turkey

Gsm: +90 5054547589 E-mail: elozdr@gmail.com

O) Journal of Clinical Research in Pediatric Endocrinology, Published by Galenos Publishing 
Bone age was 11 years. Midparental height (MPH) was $151.8 \mathrm{~cm}$ (3-10p). At physical examination, abdominal obesity and scoliosis of the lumbar vertebrae were noted. Inspection also revealed a thin upper lip, prognathism and ear auricle anomaly. The $4^{\text {th }}$ and $5^{\text {th }}$ metacarpals of both hands were short and overriding of the toes was present. The thyroid gland was nonpalpable. Pubertal status was compatible with stage 3. A systolic murmur was heard in all heart focuses. Bilateral hearing loss and right nystagmus were also present. Laboratory examination results showed that serum lipid values were in the upper normal range (total cholesterol: $176 \mathrm{mg} / \mathrm{dL}$, triglyceride: $187 \mathrm{mg} / \mathrm{dL}$ ) and that her thyroid stimulating hormone (TSH) level was high $(8.16 \mathrm{IU} / \mathrm{mL})$. Her anti-thyroid peroxidase (anti-TPO) level was $83.9 \mathrm{lU} / \mathrm{mL}$ and her anti-thyroglobulin (anti-TG) level was $92.6 \mathrm{IU} / \mathrm{mL}$. Thyroid imaging revealed a thyroid volume of $7.3 \mathrm{~mL}$. The patient was diagnosed to have Hashimoto thyroiditis and subclinical hypothyroidism and was started on L-thyroxine (L-T4). Immunoglobulin A (IgA) values were measured and found to be normal. Insulin-like growth factor-1 (IGF-1) and IGF binding protein-3 (IGFBP-3) levels were low $(<-2$ SD) for age.

At follow-up, annual height growth rate was $6.5 \mathrm{~cm} /$ year. Weight gain was also found to be accelerated. At 13 years and 8 months, acanthosis nigricans appeared on the neck and armpits and striae in the lumbar regions. In a review of her history, no laboratory data suggesting iatrogenic Cushing's disease were found, but the patient had received local steroid treatment for atopic eczema for approximately 3 years.

Metformin therapy was started following determination of a peak insulin level of $400 \mathrm{IU} / \mathrm{mL}$. Oral glucose tolerance test (OGTT) was performed and homeostatic model assessment of IR (HOMA-IR) was measured at 5.7. The patient lost weight and IR regressed with treatment (HOMA-IR: 2.43).

Chromosomal structure in our patient was deletion of 18 (q21.31-q23). Genes with deletion were identified as RAX, LMAN1, TNFRSF11A, BCL2, MC4R, FVT1 and CTDP1 using comparative genomic hybridization (CGH).

\section{Case Report 2}

A female patient aged 13 years and 3 months was referred to the pediatric endocrinology outpatient clinic from the allergy department due to her being overweight.

The patient's birth history was normal. She was born by normal vaginal delivery, with a birth weight of $3500 \mathrm{~g}$. Increased weight was noted to develop at age 5 or 6 . The patient was also reported to have mental retardation and retardation in motor development. She walked at age 3 and talked around age 5-6 years. The patient was under psychiatric observation for her mental retardation and behavioral problems and had been given Risperdal. She also was reported to have allergic asthma from birth. The parents were second-degree relatives. Two siblings (a girl and a boy) were alive and healthy.
The patient's weight was $61 \mathrm{~kg}$ (1.8 SDS) and her height was $140 \mathrm{~cm}$ (-2.68 SDS). Her bone age was 12 years. Body mass index was 30 , compatible with her proportionate short stature.

Physical examination revealed a patient with a short neck, a broad nasal bridge, a downturned mouth and prognathism. Marked acanthosis nigricans was observed on her neck. Shortness of the $4^{\text {th }}$ and $5^{\text {th }}$ metacarpals and cubitus valgus were also present. Puberty was compatible with stage 5 .

Thyroid function test results [TSH: $798 \mathrm{IU} / \mathrm{mL}$, free T4 (fT4): $0.160 \mathrm{ng} / \mathrm{dL}$, anti-TPO: $800 \mathrm{lU} / \mathrm{mL}$ and anti-TG: $869 \mathrm{lU} / \mathrm{mL}$ ] were compatible with autoimmune thyroiditis. Due to high TSH values, a pituitary MR was performed and adenoma was ruled out. Ultrasonographic evaluation results were also in line with a diagnosis of thyroiditis (thyroid volume: $8.7 \mathrm{~mL}$ ). Dyslipidemia (triglycerides: $575 \mathrm{mg} / \mathrm{dL}$, total cholesterol: $337 \mathrm{mg} / \mathrm{dL}$ ) and hyperinsulinism with a peak value of $130 \mathrm{mU} / \mathrm{mL}$ measured during OGTT were the other pathologies identified. IgA values were measured and found to be normal. IGF-1 and IGFBP-3 levels were low (<-2 SD) for age.

Urinary ultrasound revealed a horseshoe kidney. Cardiologic examination was normal. Auditory tests revealed bilateral hearing loss.

Peripheral blood karyotype analysis of this patient also revealed deletion in the regions of 21.3-23, belonging to the long arms of the $18^{\text {th }}$ chromosome.

Clinical and laboratory data on the two patients are given in Tables 1 and 2. Facial appearance of the two patients is demonstrated in Figures 1 and 2. Results of genetic analysis are presented in Figures 3 and 4.

Table 1. Clinical findings in our two patients

\begin{tabular}{|c|c|c|}
\hline & Case 1 & Case 2 \\
\hline \multicolumn{3}{|l|}{ Dysmorphic signs } \\
\hline - Broad nasal bridge & + & + \\
\hline - Downturned mouth & + & + \\
\hline - Prognathism & + & + \\
\hline - Microcephaly & + & + \\
\hline Cardiologic defects & $\begin{array}{l}\text { Aortic stenosis } \\
\text { Mitral insufficiency }\end{array}$ & None \\
\hline Allergic disease & $\begin{array}{l}\text { Allergic asthma } \\
\text { Atopic eczema } \\
\text { Celiac disease }\end{array}$ & Allergic asthma \\
\hline Intellectual disability & Wisc-R 40\% & Wisc-R $60 \%$ \\
\hline Renal pathology & Normal & Horseshoe kidney \\
\hline Hearing impairment & $50 \%$ & $50 \%$ \\
\hline
\end{tabular}




\begin{tabular}{|llll|}
\hline \multicolumn{4}{|c|}{ Table 2. Laboratory findings in our two patients } \\
\hline & Case 1 & Case 2 & Reference values \\
\hline Fasting blood glucose & $71 \mathrm{mg} / \mathrm{dL}$ & $78 \mathrm{mg} / \mathrm{dL}$ & $70-100 \mathrm{mg} / \mathrm{dL}$ \\
Insulin & $24 \mathrm{uU} / \mathrm{mL}$ & $16 \mathrm{uU} / \mathrm{mL}$ & $0-17 \mathrm{uU} / \mathrm{mL}$ \\
OGTT peak insulin & $398 \mathrm{uU} / \mathrm{mL}$ & $133 \mathrm{uU} / \mathrm{mL}$ & \\
Total cholesterol & $176 \mathrm{mg} / \mathrm{dL}$ & $575 \mathrm{mg} / \mathrm{dL}$ & $70-200 \mathrm{mg} / \mathrm{dL}$ \\
Triglycerides & $187 \mathrm{mg} / \mathrm{dL}$ & $337 \mathrm{mg} / \mathrm{dL}$ & $190-129 \mathrm{mg} / \mathrm{dL})$ \\
TSH & $8.61 \mu \mathrm{U} / \mathrm{mL}$ & $768 \mu U / \mathrm{mL}$ & $0.55-3 \mu \mathrm{U} / \mathrm{mL}$ \\
fT4 & $1.10 \mathrm{ng} / \mathrm{dL}$ & $0.16 \mathrm{ng} / \mathrm{dL}$ & $0.59-1.59 \mathrm{ng} / \mathrm{L}$ \\
Anti-TPO & $83 \mathrm{IU} / \mathrm{mL}$ & $800 \mathrm{IU} / \mathrm{mL}$ & $0-30 \mathrm{IU} / \mathrm{mL}$ \\
Anti-TG & $92 \mathrm{IU} / \mathrm{mL}$ & $877 \mathrm{IU} / \mathrm{mL}$ & $0-30 \mathrm{IU} / \mathrm{mL}$ \\
IgA & $142 \mathrm{mg} / \mathrm{dL}$ & $102 \mathrm{mg} / \mathrm{dL}$ & $80-350 \mathrm{mg} / \mathrm{dl}$ \\
IGF-1 & $353 \mathrm{ug} / \mathrm{L}$ & $364 \mathrm{ug} / \mathrm{L}$ & $217-580 \mathrm{ug} / \mathrm{L}$ \\
IGFBP-3 & $4413 \mathrm{ng} / \mathrm{mL}$ & $3647 \mathrm{ng} / \mathrm{mL}$ & $2500-4800 \mathrm{ng} / \mathrm{mL}$ \\
Karyotype & $18 \mathrm{q} 21.32$ & $18 \mathrm{q} 21.32$ & \\
\hline
\end{tabular}

OGTT: oral glucose tolerance test, TSH: thyroid stimulating hormone, $\mathrm{TT} 4$ : free thyroxine, Anti-TPO: anti-thyroid peroxidase, Anti-TG: anti thyroglobulin, IgA: immunoglobulin A, IGF-1: insulin-like growth factor-1, IGFBP-3: IGF binding protein-3

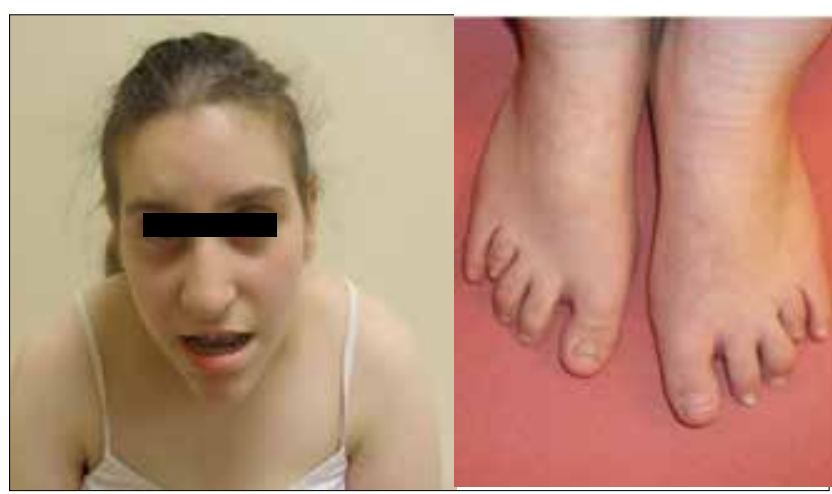

Figure 1. Facial and foot appearance of Case 1

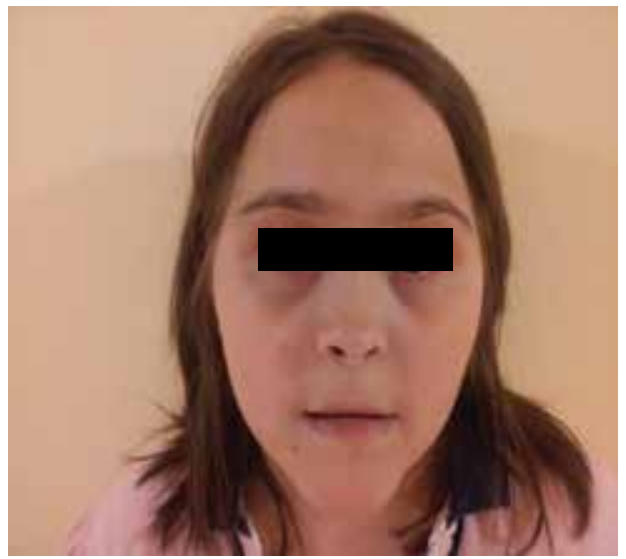

Figure 2. Facial appearance of Case 2

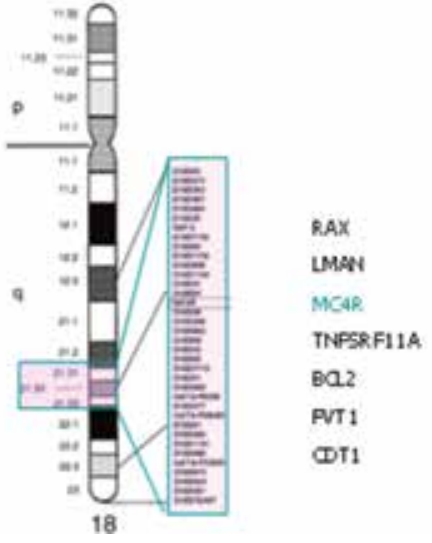

Figure 3. Chromosome 18

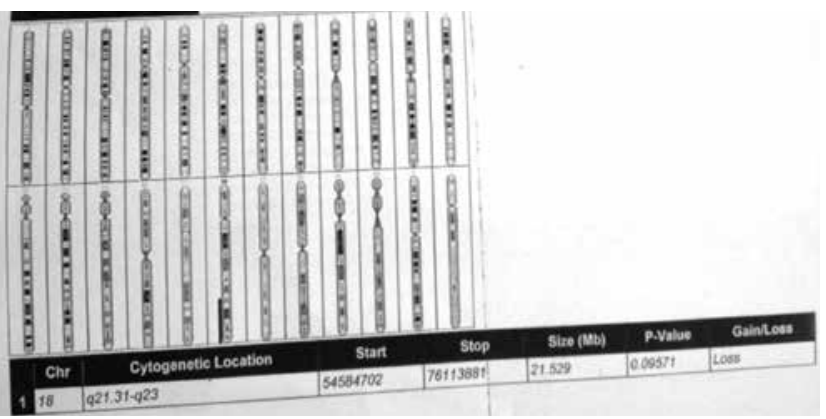

Figure 4. Image of a comparative genomic hybridization (CGH)

\section{Discussion}

The most common findings of $18 q$ Deletion syndrome, which has a wide phenotype, are a characteristic facial appearance (microcephaly, palatal defects, a carp-shaped mouth, a short palpebral fissure and outer ear abnormalities), mental retardation, short stature, hypotonia, hearing loss and feet deformities $(1,2)$. Deletion of $18 q 22.3$ is the chromosomal abnormality in which typical clinical findings are most commonly seen.

All components generally reported in the literature were present in our cases. Nystagmus, strabismus, optic atrophy and retinal degeneration have been reported in addition to auricular findings and hearing defects (1). Optic atrophy and nystagmus were present in our Case 1. The reported incidence of cardiac defects is approximately $24 \%$; of these, atrial and ventricular septal defects, absent pulmonary valve, pulmonary stenosis and aortic valve defects are the most common (3). While Case 1 was being followed by the cardiology department with a diagnosis of bicuspid aortic valve and valvular aortic stenosis, cardiological examination of Case 2 was normal. Gunes et al (4) reported mitral insufficiency in a case with an 18q21-qter karyogram.

External ear anomalies and hearing loss are also among the major components of the syndrome (1). Auricular anomaly and a sensorineural hearing loss of $50 \%$ were found in Case 1 and a hearing loss of $40 \%$ with no auricular anomaly was found in Case 2. 
One of the most important findings in these cases is short stature; a height SDS below -2 is reported in $64 \%$ of these patients and annual height growth rates are below average values in $70 \%$ of the cases. Approximately $70 \%$ of the cases show an inadequate growth hormone $(\mathrm{GH})$ response in stimulation tests (5).

Height percentiles were below -2.5 SDS in both our cases. Annual growth rate in Case 1 was more than $5 \mathrm{~cm} /$ year until menarche and $2 \mathrm{~cm} /$ year thereafter. Case 2 was referred to us when she was at Tanner stage 5, after which annual growth rate was $1 \mathrm{~cm} /$ year. Unfortunately, we were not able to perform GH stimulation tests in our two patients, but IGF-1 and IGFBP-3 levels in both cases were below -2 SDS for chronological and bone age. Since height velocity appeared to be near normal in Case 1 and could be estimated only after a late stage of puberty in Case 2, we can hypothesize that the short stature in both cases was probably the result of poor growth in early childhood, possibly due to inadequate $\mathrm{GH}$ secretion.

Susceptibility to autoimmune diseases is significantly lower in $18 q$ Deletion syndrome compared to the normal population. An association has been reported between the 18q21 region and diseases such as Hashimoto, Graves, rheumatoid arthritis and type 1 diabetes. Autoimmunity-related IgA deficiency has also been observed. According to some authors, deletions in the $18 q$ chromosome affect critical genetic loci, resulting in activated autoimmunity. On the other hand, no immunoglobulin genes are encoded on the 18th chromosome and IgA deficiency has also been reported in other $18^{\text {th }}$ chromosomal abnormalities (ring chromosome 18 and $18 q$ Deletion syndrome) as well as from 18q Deletion syndrome.

$\lg A$ deficiency is seen approximately in $24 \%$ of cases but not in all patients with activated autoimmunity (6). The IgA levels of our patients were normal.

While a moderately high TSH level was detected in Case 1 during routine laboratory tests for short stature, TSH and autoantibody levels in Case 2, admitted for obesity and short stature, were very high. Autoimmune thyroiditis in our cases indicated active autoimmunity and also suggested an allergic affinity. Autoimmune hyperthyroidism has also been rarely reported (7).

Obesity has been reported in cases with 18q12.2;21.1 deletion and this may be related to the amount of deleted genes (8). Patients with this karyogram have a different facial appearance to the classical one and are often obese. This relationship suggests a genotype and phenotype correlation in 18q Deletion syndrome.

Fenestra et al (9) analyzed the chromosomal structure of 29 syndromic cases using the CGH technique. They determined six cases with proximal deletion, 22 with terminal deletion and aberration between different chromosomes in one patient. The syndrome has been found to be associated with microcephaly (18q21.33), short stature (18q12.1-q12.3 18q21.1-q21.33, 18q22.3-q23), delayed myelination (18q22.3-q23), GH deficiency (18q22.3-q23) and congenital aural atresia (18q22.3). The main critical point for $18 \mathrm{q}$ Deletion syndrome has been identified as the 4.3Mb 18q22.3-q23 region (9).

In a study of 151 cases, Cody identified the region which determines phenotype as 18q22.3-q23. Five genes regulating demyelination and response to $\mathrm{GH}$, four genes dealing with renal malformation and three genes related to aural atresia were detected in this region (10).

The chromosomal structure of our patients was 18(q21.31-q23). Array CGH identified the genes with deletion as RAX, LMAN1, TNFRSF11A, BCL2, MC4R, FVT1 and CTDP1. While the loss of the MC4R gene is a probable cause of obesity in the affected cases (11), the presence of horseshoe kidney in our Case 2 may also be associated with this loss (Figure 3).

In conclusion, this report on two rare cases emphasizes the importance of karyogram analysis in cases with more than one endocrine pathology accompanied by hearing loss and mental retardation.

\section{References}

1. Cody JD, Ghidoni PD, DuPont BR, Hale DE, Hilsenbeck SG, Stratton RF, Hoffman DS, Muller S, Schaub RL, Leach RJ, Kaye $\mathrm{Cl}$. Congenital anomalies and anthropometry of 42 individuals with deletions of chromosome 18q. Am J Med Genet 1999;85:455-462.

2. Leisti J, Leisti S, Perheentupa J, Savilahti E, Aula P. Absence of IgA and growth hormone deficiency associated with short arm deletion of chromosome 18. Arch Dis Child 1973;48:320-322.

3. Versacci P, Digilio MC, Sauer U, Dallapiccola B, Marino B. Absent pulmonary valve with intact ventricular septum and patent ductus arteriosus: a specific cardiac phenotype associated with deletion 18q syndrome. Am J Med Genet A 2005;138:185-186.

4. De novo $18 \mathrm{q}$ deletion with mitral valve insufficiency. Gunes S, Okten G, Kara N, Saglam Y, Tasdemir HA, Kayacik OE, Tural SGenet Couns. 2008;19(3):261-5

5. Hale DE, Cody JD, Baillargeon J, Schaub R, Danney MM, Leach RJ. The spectrum of growth abnormalities in children with $18 q$ deletions. J Clin Endocrinol Metab 2000;85:4450-4454.

6. Lewkonia RM, Lin CC, Haslam RH. Selective IgA deficiency with $18 q+$ and 18q- karyotypic anomalies. J Med Genet 1980;17:453-456.

7. Tutunculer F, Darendeliler F, Gunoz H, Karaman B, Kayserili $H$. $18 \mathrm{q}$ deletion syndrome associated with autoimmune thyroid disease presenting as hyperthyroidism. J Pediatr Endocrinol Metab. 2005 Apr; 18(4):419-20

8. Wilson GN, Al Saadi AA. Obesity and abnormal behaviour associated with interstitial deletion of chromosome 18 (q|2.2q21.1). J Med Genet 1989;26:62-63.

9. Feenstra I, Vissers LE, Orsel M, van Kessel AG, Brunner HG, Veltman JA, van Ravenswaaij-Arts CM. Genotype-phenotype mapping of chromosome $18 q$ deletions by high-resolution array CGH: an update of the phenotypic map. Am J Med Genet 2007;143:1858-1867.

10. Cody JD, Heard PL, Crandall AC, Carter EM, Li J, Hardies LJ, Lancaster J, Perry B, Stratton RF, Sebold C, Schaub RL, Soileau B, Hill A, Hasi M, Fox PT, Hale DE. Narrowing critical regions and determining penetrance for selected 18q- phenotypes. Am J Med Genet 2009;149A:1421-1430.

11. Cody JD, Reveles XT, Hale DE, Lehman D, Coon $H$, Leach RJ. Haplosufficiency of the melanocortin-4 receptor gene in individuals with deletions of 18q. Hum Genet 1999;105:424427. 